\title{
Economic Benefits of Rearing Male chicks Evaluation of standards
}

\author{
Caspar von der Crone \\ $\mathrm{PhD}$-Student \\ Graduate Engineer Agrarian Sciences \\ Faculty of Economics, Hungary \\ University of Sopron
}

\begin{abstract}
The killing of male chicks is considered very emotionally. That is why the economy in many countries of the EU and beyond has been looking for solutions for a long time. Embryonic early detection is an important approach, but it involves considerable effort and costs. The results to date are not yet effective. On the one hand there is criticism from the animal protection organizations, on the other hand the effort for a commercial selection is considerable and costintensive. Ecological production, however, offers alternatives. The market is structured differently. Consumers have specific expectations, both in terms of animal welfare standards, the origin of organic products and the price. From an ideological point of view, the buyer class is quite willing to pay more for organically produced products. The so-called dual-use chickens are an option to meet the expectations of non-governmental organizations (NGO's) and consumers with regard to animal welfare. The type of husbandry is also cost-intensive due to a lower laying performance and compared to conventional broiler fattening with a poorer feed conversion. Organic producers are therefore increasingly relying on the rearing of male chicks. There are no legal criteria for rearing so far. The interest group Bio-Initiative (IG Bio) has therefore defined binding standards on the basis of ecological principles. This means, for example: specifications for barn equipment, stocking density, perches, usable areas, water, feed and discharge. The production costs for this are also higher, but due to the emotional approaches better sales opportunities are possible in the food trade and especially in the convenience sector. The Bio-Initiative has obligated the participating farms not to kill any more male chicks, but to feed them 100\% to the rearing. The recycling also makes an important contribution to the protection of animals.
\end{abstract}

\section{The Situation}

Ecological production forms an overall system of farm management and food production, the best environmentally friendly method, a high degree of species diversity, the protection of natural resources and the application of high animal welfare and production standards. The aim is to meet the growing consumer demand for organic products produced using natural substances and processes. Organic production also makes an important contribution to environmental protection, animal welfare and rural development. The compliance of organic production with high health, environmental and animal welfare standards is therefore essential.

The objectives of organic production fit in with those of the common agricultural policy. Organic production is based on REGULATION (EU) 2018/848 OF THE EUROPEAN PARLIAMENT AND OF THE COUNCIL of 30 May 2018 laying down detailed rules for the implementation of Council Regulation (EC) No 834/2007 on organic production and labelling of organic products with regard to organic production, labelling and control. The latter Regulation is currently being adapted and refocused with the implementing rules. Entry into force is planned for 2021.

\section{Hypotheses:}

H1: The rearing of male chicks is not economically effective and exclusively pursues the interests of animal welfare activists.

H2: High prices for the products are not accepted by food retailers and consumers and therefore do not provide a basis for an economically viable approach.

H3: The killing of male chicks is prohibited by law and the economy is forced to find ecologically sensible solutions. H4: It is a model for the future that is becoming the standard within the EU and is also a target in other countries.

\section{3: Methodology}

For the evaluation of standards in the field of the rearing of male chicks of laying hybrids there are no scientific statements. Only the so-called poussin breeding gives a certain pattern, which has however no commercial background. 
The basis of the assessment therefore refers to the Livestock Welfare Initiative (LWL), which has developed standards for the assessment of animal welfare claims. On the basis of an evaluation scheme, it is emphasized on a neutral basis how the respective standards of the system providers are to be assessed. This includes the entire animal processing. In addition, there are parameters for traceability along the process chain. The focus is on animal welfare, traceability and controls.

With the definition of clear evaluation criteria, according to the state of the art of research and science, which take into account animal behavior, aspects of husbandry, management and animal health must be equally taken into account. This includes a clarification of the added value for the consumer through a label with recognition value. The BIOInitiative community of interests has taken these guidelines as a basis and established standards for the rearing of male chicks of laying hybrids. These are the basis for the following evaluation.

\section{Definition and definition of terms}

The EU marketing standards for eggs and poultry define requirements for poultry farming in the conventional sector. Standards for organic farming are laid down in the Organic Farming Ordinance. In both Regulations there are no parameters for the rearing of chicks and pullets. This is incumbent, if at all, on the respective standard setters of certain labels.

The organic initiative, on the other hand, has set clear guidelines for rearing. The killing of male chicks is completely prohibited from 2019 and is considered a knockout criterion. The animals shall be reared together under the same conditions as female animals. It is therefore not a mast that is built according to completely different criteria, both conventional and organic. A separation of the animals takes place only after 10 weeks. Afterwards the animals will be provided with an exercise area of $4 \mathrm{sqm}$. This is associated with high costs, which have to be enforced on the market. There are three types of chicken production:

- Egg production

In egg-producing holdings, laying hens are kept in aviaries, in barn systems with or without exercise. After one to two production cycles, the hens are sold or processed as soup chickens.

- Fattening

Broiler fatteners use high-calorie feed in order to safely achieve the highest and quickest possible weight gains. A distinction is made between fast-growing and slow-growing breeds, the latter especially for organic production.

- Rearing

Rearing farms keep chicks which are reared as pullets and are intended for egg production. The male animals are not desirable for meat production in the conventional area and are killed after hatching. In the area of the organic initiative, the chicks are reared together.

\section{Legal framework of the EU Eco-Regulation}

REGULATION (EU) 2018/848 OF THE EUROPEAN PARLIAMENT AND OF THE COUNCIL of 30 May 2018 on organic production and labelling of products and repealing Council Regulation (EC) No 834/2007

Table 1: Requirements for poultry from organic farming (Status: Regulation (EC) No 834/2007)

\begin{tabular}{|c|c|c|c|c|}
\hline \multirow[t]{2}{*}{ EU-Requirements } & \multicolumn{3}{|c|}{ Indoors area (net area avilable to anmimals) } & \multirow[b]{2}{*}{$\begin{array}{c}\text { Outdoor area }\left(\mathrm{m}^{2} \text { of }\right. \\
\text { area avaiable in } \\
\text { rotation/head) }\end{array}$} \\
\hline & No animals/m2 & cm perch/animal & nest & \\
\hline Laying hens & 6 & 18 & $\begin{array}{c}7 \text { laying hens per } \\
\text { nest or in case of } \\
\text { common nest } 120 \\
\mathrm{~cm}^{2} / \text { bird }\end{array}$ & $\begin{array}{l}4 \text { broilers and guinea } \\
\text { fowl. In all the } \\
\text { species mentional } \\
\text { above the limit of } \\
170 \mathrm{~kg} \text { of } \mathrm{N} / \mathrm{ha} / \mathrm{year} \\
\text { is not exeeded. }\end{array}$ \\
\hline $\begin{array}{l}\text { Fattening poultry (in } \\
\text { fixed housing) }\end{array}$ & $\begin{array}{c}10 \text { with a maximum } \\
\text { of } 21 \mathrm{~kg} \\
\text { liveweight } / \mathrm{m} 2\end{array}$ & $\begin{array}{l}20 \text { (for guinea fowl } \\
\text { only) }\end{array}$ & & \\
\hline $\begin{array}{c}\text { Fatteing poultry in } \\
\text { mobile housing }\end{array}$ & $\begin{array}{c}16 \text { in mobile poultry } \\
\text { houses with a } \\
\text { maximum of } 30 \mathrm{~m} \mathrm{~kg} \\
\text { liveweight/m } \mathrm{m}^{2}\end{array}$ & & & $\begin{array}{c}2,5, \text { provided thst the } \\
\text { limit of } 170 \mathrm{~kg} \text { of } \\
\mathrm{N} / \mathrm{ja} / \mathrm{year} \text { is not } \\
\text { exceeded }\end{array}$ \\
\hline
\end{tabular}




\begin{tabular}{|c|c|c|c|c|}
\hline \multirow[t]{2}{*}{ EU-Requirements } & \multicolumn{3}{|c|}{ Indoors area (net area avilable to anmimals) } & \multirow[b]{2}{*}{$\begin{array}{c}\text { Outdoor area }\left(\mathrm{m}^{2} \text { of }\right. \\
\text { area avaiable in } \\
\text { rotation/head) }\end{array}$} \\
\hline & No animals/m2 & cm perch/animal & nest & \\
\hline Laying hens & 6 & 18 & $\begin{array}{c}7 \text { laying hens per nest or } \\
\text { in case of common nest } \\
120 \mathrm{~cm}^{2} / \text { bird }\end{array}$ & $\begin{array}{l}4 \text { broilers and guinea } \\
\text { fowl. In all the species } \\
\text { mentional above the } \\
\text { limit of } 170 \mathrm{~kg} \text { of } \\
\mathrm{N} / \mathrm{ha} / \text { year is not } \\
\text { exeeded. }\end{array}$ \\
\hline $\begin{array}{l}\text { Fattening poultry (in } \\
\text { fixed housing) }\end{array}$ & $\begin{array}{c}10 \text { with a maximum of } \\
21 \mathrm{~kg} \text { liveweight } / \mathrm{m} 2\end{array}$ & 20 (for guinea fowl only) & & \\
\hline $\begin{array}{l}\text { Fatteing poultry in } \\
\text { mobile housing }\end{array}$ & $\begin{array}{c}16 \text { in mobile poultry } \\
\text { houses with a maximum } \\
\text { of } 30 \mathrm{~m} \mathrm{~kg} \\
\text { liveweight } / \mathrm{m}^{2}\end{array}$ & & & $\begin{array}{l}\text { 2,5, provided thst the } \\
\text { limit of } 170 \mathrm{~kg} \text { of } \\
\mathrm{N} / \mathrm{ja} / \text { year is not } \\
\text { exceeded }\end{array}$ \\
\hline
\end{tabular}

Source: EUROSTAT

\section{Basically:}

In order to avoid intensive rearing methods, poultry is reared either until a minimum age is reached or must come from slow-growing breeds/lines adapted to free-range rearing. If slow-growing breeds/lines are not used, the minimum age at slaughter shall be 81 days for chickens.

\section{The same applies to nutrition:}

At least $30 \%$ of feed must come from the holding itself or, if this is not possible or not available, be produced in cooperation with other organic production units or production units in conversion and feed business operators using feed and feed materials from the same region.

Fresh, dried or ensiled roughage must be added to the daily ration of poultry. If no organically produced protein feeds are available and the competent authority confirms this, non-organic protein feeds may be used under certain conditions until 31 December 2025.

\section{Animal welfare:}

As far as housing and husbandry practices are concerned, at least one third of the floor area shall be of solid quality and shall be covered with litter material in the form of straw, wood shavings, sand or peat. Poultry must have access to the outdoor area for at least one third of their lifetime, from the earliest possible age whenever physiological and physical conditions permit. The outdoor area must consist mainly of a vegetation cover. The total usable floor area of stables shall not exceed $1,600 \mathrm{~m} 2$ for any production unit.

For housing and husbandry practices applies:

At least one third of the floor area must be solid, i.e. it must not be slatted or grated and must be covered with litter in the form of straw, wood shavings, sand or peat.

Poultry must have access to open-air areas for at least one third of their lifetime. Exercise shall be unrestricted from the earliest possible age during the day whenever physiological and physical conditions permit, except in the case of temporary restrictions provided for under Union law. The open-air area for poultry must provide unhindered access for the animals to an adequate number of watering places and consist mainly of a vegetation cover. The total usable area of stables for the wing mast may not exceed $1,600 \mathrm{~m} 2$ for any production unit.

The organic regulation prescribes $4 \mathrm{~m} 2$ per animal for the fattening of chickens and guinea fowl. However, male chicks are not broiler chickens but hybrid chicks, which inevitably accumulate in half when hatched. However, the breeding goal was laying chicks, combined with the goal of achieving the highest possible laying performance. No breeding of the male animals was planned, as this proved to be unprofitable and therefore the chicks were killed immediately after hatching. This is prohibited in the area of BIO-Initiative $\mathrm{gGmbH}$ for ethical and ideological reasons.

\section{Private law requirements of the Bio-Initiative}

The main objective of the BIO initiative is to establish standards and quality assurance programs for organic production in the plant and animal sectors, thus providing a simple, transparent and easily understandable evaluation of products. 
Ultimately, however, there is also the specification of how much animal welfare is taken into account in the production of a product. As a result, higher standards and more animal welfare for producers justify a better positioning on the market and vis-à-vis competitors.

Organic eggs and/or organic poultry meat, which are offered with the note of cock rearing from the laying line (including brother chicks, brother cock, rearing of cock and hen, or the like), are subject to the following provisions:

Since there are no EU requirements for the rearing of mixed-gender rearing, the requirements of the Organic Farming Initiative apply to the combined rearing of young hens and cocks (brother cocks).

Table 2: EU requirements versus requirements Bio-Initiative

\begin{tabular}{|c|c|c|c|}
\hline Contents & Requirements & EU-Bio & Bio-Initiative (B-I) \\
\hline \multirow{5}{*}{ Young cocks } & Stocking density in the barn & $\max .4 .800$ & max. 4.800 young cocks \\
\hline & $\begin{array}{l}\text { Square meters of run per animal } \\
\text { (from 11th week of life) }\end{array}$ & no regultation & $\begin{array}{l}\min .4 \mathrm{~m}^{2} \text {, availability is always mandatory, in } \\
\text { addition a roofed and wind-protected outlet must be } \\
\text { available all year round for periods of bad weather }\end{array}$ \\
\hline & slaughter age & no regultation & mind. 91 days or $1,6 \mathrm{~kg}$ live weight \\
\hline & origin of the chicks & no regultation & $\begin{array}{l}\text { of ecological origin, from the same hatching of } \\
\text { female animals }\end{array}$ \\
\hline & rearing & no regulation & common rearing of male and female chicks \\
\hline
\end{tabular}

Source: Own survey

Table 3: Specifications of the Bio-Initiative for the rearing of Brother Cock Chicks.

\begin{tabular}{|c|c|c|c|c|c|}
\hline \multicolumn{6}{|c|}{ Movement, social contact } \\
\hline \multirow{2}{*}{$\begin{array}{l}\text { stocking density } \\
\text { Animals/groups }\end{array}$} & \multicolumn{3}{|c|}{ animals $/ \mathrm{m}^{2}$ (usable stocking densityarea) or $21 \mathrm{~kg} / \mathrm{m}^{2}$} & \multicolumn{2}{|c|}{ outlet } \\
\hline & up to 10 th day of life & $\begin{array}{l}\text { from } 11 \text { th to } 34 \text { th } \\
\text { day of life }\end{array}$ & from 35 th day of life & $\begin{array}{c}\text { from } 10 \text { th week of } \\
\text { life m2 per young } \\
\text { hen }\end{array}$ & covered run \\
\hline 4.800 & 100 & 50 & 18 & 4 & $\begin{array}{l}\text { artial use as outlow } \\
\text { possible }\end{array}$ \\
\hline \multicolumn{6}{|l|}{ Perches } \\
\hline Perches & availability & rrangement & $\begin{array}{l}\text { perch length } \\
(\mathrm{cm} / \text { animal })\end{array}$ & $\begin{array}{l}\text { distance of perches, } \\
\mathrm{cm}\end{array}$ & $\begin{array}{l}\text { free space above the } \\
\text { sitting days, cm }\end{array}$ \\
\hline $\begin{array}{c}\text { from the first day of } \\
\text { life available }\end{array}$ & $\begin{array}{l}\text { from } 35 \text { th day of life } \\
\text { for all animals }\end{array}$ & different heights & $\begin{array}{l}\text { bis } 10 . \mathrm{LW}>6 \mathrm{~cm} \text {, } \\
\text { ab } 10 . \mathrm{LW}>10 \mathrm{~cm} \text {, } \\
\text { ab } 15 . \mathrm{LW}>15 \mathrm{~cm}\end{array}$ & $>20$ & $>45$ \\
\hline \multicolumn{6}{|l|}{ Light } \\
\hline $\begin{array}{l}\text { Light, proportion of } \\
\text { floor space in the } \\
\text { stable }\end{array}$ & Illumination & Luminous intensity & dark phase & & \\
\hline $\begin{array}{l}5 \% \text { natural light } \\
\text { incidence }\end{array}$ & evenly & $\begin{array}{c}>20 \text { lux at eye level } \\
\text { of the animals }\end{array}$ & $\begin{array}{c}\text { from } 15 \text { th day of life } \\
8 \text { hours }\end{array}$ & & \\
\hline \multicolumn{6}{|c|}{ Availability of facilities (feed, water) } \\
\hline \multicolumn{2}{|l|}{$\begin{array}{l}\text { Feeding place } \\
\text { (cm/animal Trough } \\
\text { side length) }\end{array}$} & $\begin{array}{l}\text { Round troughs, cm } \\
\text { usable }\end{array}$ & $\begin{array}{l}\text { Round drinkers } \\
\mathrm{cm} / \text { animal }\end{array}$ & $\begin{array}{l}\text { Nipple or cup } \\
\text { drinkers }\end{array}$ & \\
\hline until the end of $5 \mathrm{LW}$ & from 6. LW & $\begin{array}{l}\text { until the end of } 5 / \\
\text { from } 6 \mathrm{LW}\end{array}$ & $\begin{array}{l}\text { until the end of } 5 / \\
\text { from } 6 \mathrm{LW}\end{array}$ & until 10 animals & $\begin{array}{l}\text { for } 10 \text { additional } \\
\text { animals each }\end{array}$ \\
\hline$>2,5$ & $>4,5$ & 2 or 4 & 2 or 4 & 2 & 1 \\
\hline \multicolumn{6}{|c|}{ Further specifications } \\
\hline \multicolumn{4}{|c|}{ Animals $/ \mathrm{m}^{2}$ (usable area) } & Green outlet & Slaughter age \\
\hline \multicolumn{2}{|c|}{ in permanent stables, live weight $/ \mathrm{m}^{2}$} & \multicolumn{2}{|c|}{$\begin{array}{c}\text { movable stables, live weight } / \mathrm{m}^{2} \text {, floor area } \\
\text { max. } 150 \mathrm{~m} 2\end{array}$} & $\begin{array}{l}\text { at least one third of } \\
\text { the lifetime }\end{array}$ & \\
\hline \multicolumn{2}{|c|}{10 animals, max. $21 \mathrm{~kg}$} & \multicolumn{2}{|c|}{16 animals, max. $30 \mathrm{~kg}$} & from 11 th week & $\begin{array}{l}\text { not less than } 91 \text { days } \\
\text { or } 1.6 \mathrm{~kg} \text { live weight }\end{array}$ \\
\hline
\end{tabular}

Notes:

$\mathrm{LW}=$ week of life

Equipment (perches, watering troughs, feed) are available from the 1 st day, no additional installations in the occupied barn.

Source: BIO-Initiative, own survey 


\section{Note:}

The legal requirements for the exercise area described in the Regulation are limited to the fact that poultry must have access to outdoor areas for at least one third of their lifetime and that the outdoor area for poultry must consist predominantly of a vegetation cover in order to provide shelter. In addition, the animals must have unhindered access to an appropriate number of watering troughs and feeding troughs. However, these requirements apply to fattening poultry and not to the rearing of male chicks. Neither in the current regulation nor in the draft of the new regulation on organic cultivation are there any concrete requirements or indications for this yet.

\section{Economic benefits}

From an economic point of view, rearing does not make sense. In the overall calculation, however, there are advantages because the losses are usually more than compensated for by higher egg prices. On average, 4 cents more per egg are charged for eggs from the so-called Brothercock Initiative in order to compensate for the significantly higher costs.

Table 4: Theoretical cost analysis

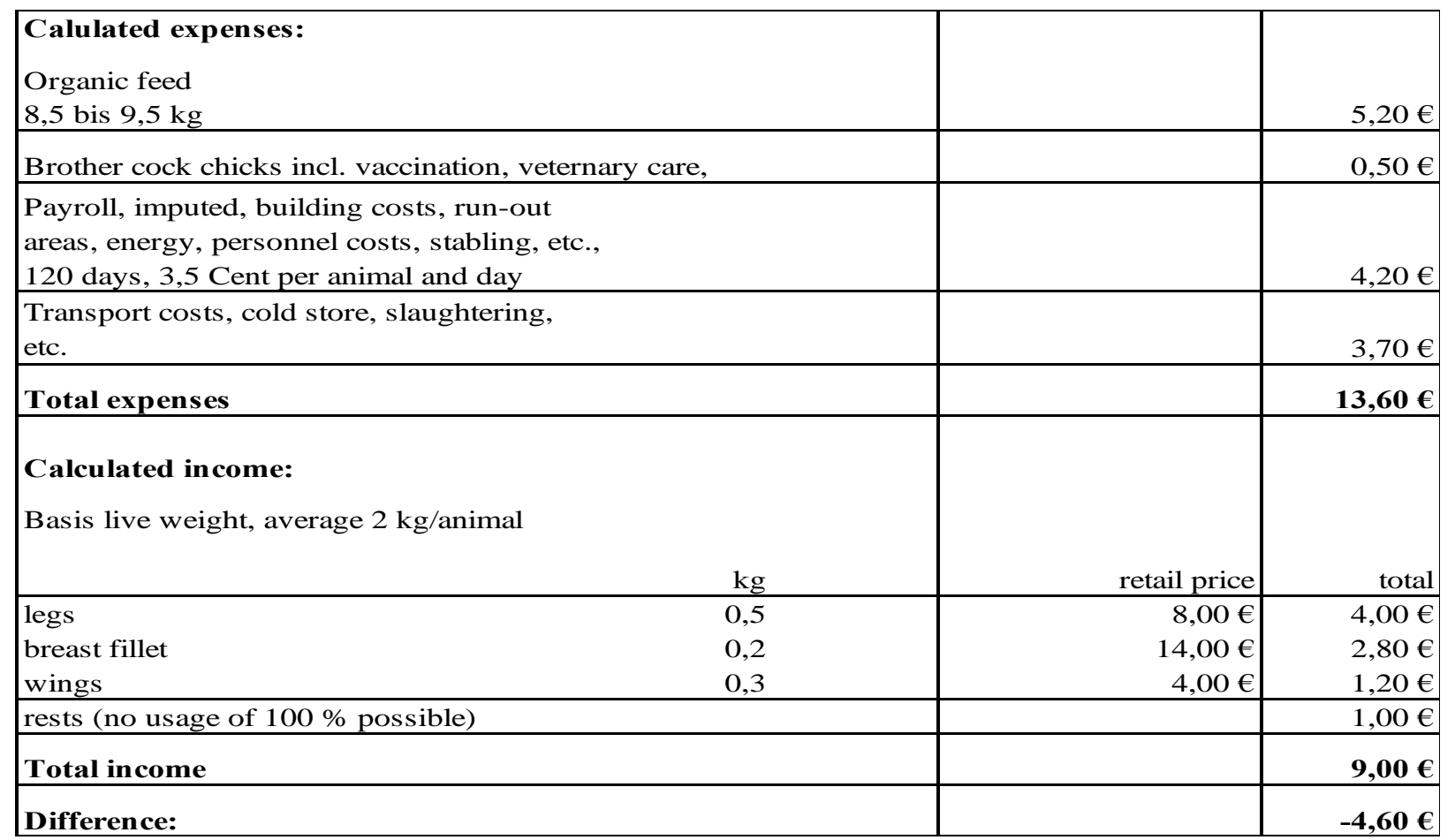

Source: BIO-Initiative, own survey

The table below shows consumer prices for eggs in Germany, showing the different revenues for each type of farming. Especially for eggs from the areas of animal welfare and ecological husbandry significantly more is achieved. This proves the willingness of consumers to spend significantly more money than on soil or outdoor goods (conventional cage farming is banned in Germany and other EU countries). The so-called brother cock initiative exists only for some years, therefore there is no statistical collection of prices for this. The basis for this is provided by our own sources. On average, the prices are up to four cents per egg above the average for standard goods from ground or free-range husbandry.

Figure 1: Consumer prices for eggs in Germany

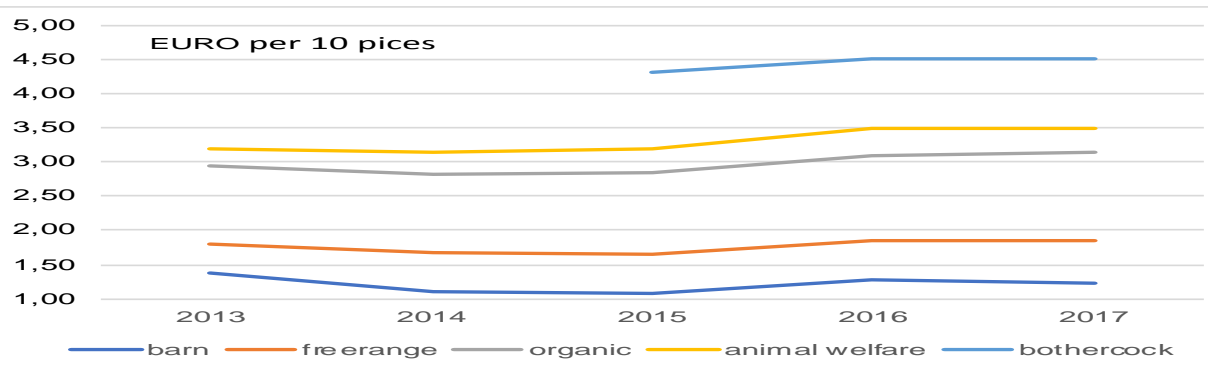

Source: MEG Yearbook 2018, own survey 
The following overview is based on our own surveys. The standard, legal requirements for the broiler mast were rated with the index 100. In the area of barn management, slowly growing breeds with additional run up into the so-called winter garden and lower stocking density, higher costs arise. This applies especially to the additional provision of an outlet in the open. The organic production has significantly longer fattening times, slow growing breeds and sets additional standards for the standard and the feed, which comes from organic production and is free of genetic engineering and contains no residues such as pesticides.

Animal welfare has less strict requirements with regard to feed, here additional criteria apply for animal welfare, in particular more free space and significantly fewer animals per square meter. The costs for the rearing of male animals are extremely high due to the high feed consumption during the long rearing period. The feed evaluation is very bad in comparison to the broilers. In addition, the animals come from ecological breeding.

Table 4: Theoretical cost analysis

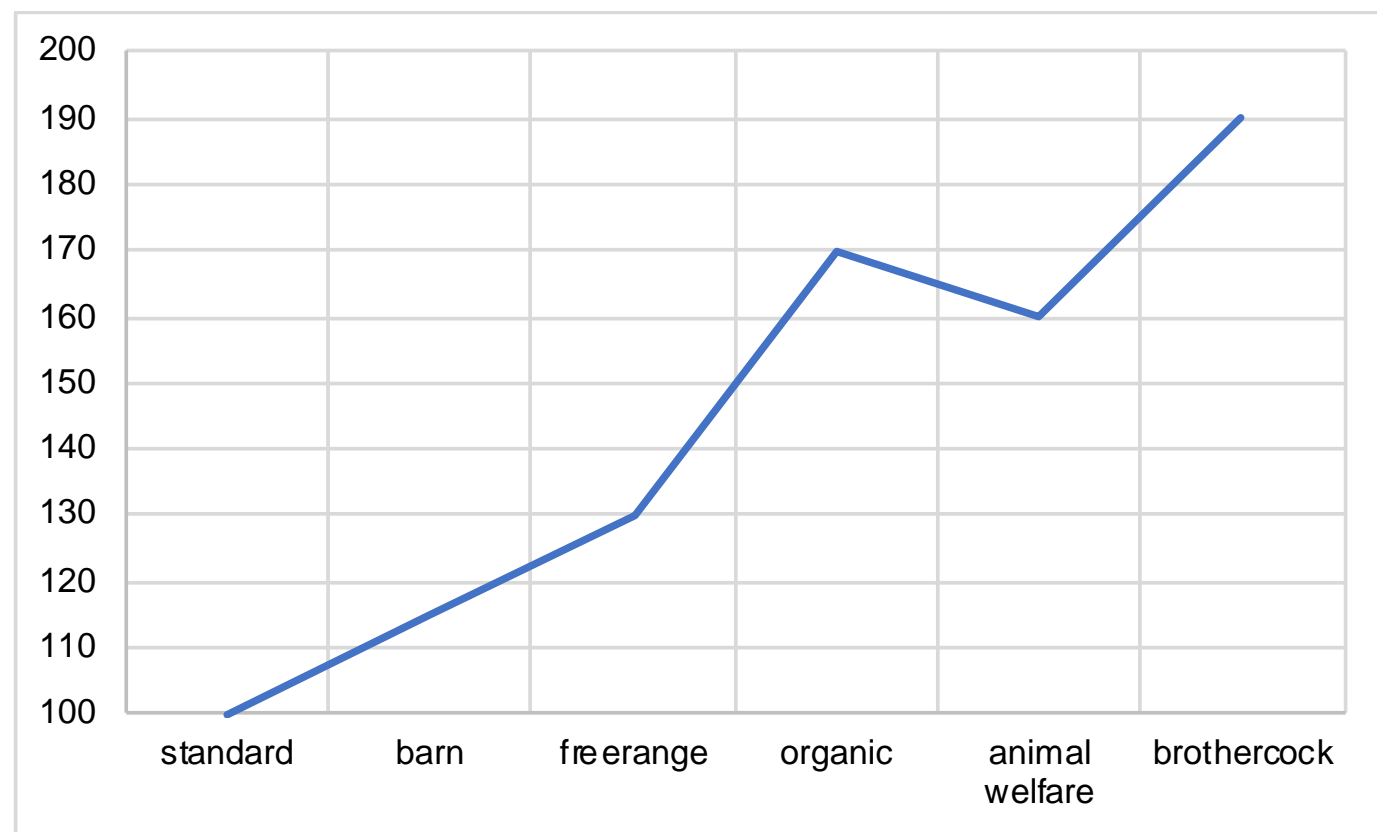

Quelle: Own survey

\section{Hypotheses:}

H1: The rearing of male chicks is not economically effective and exclusively pursues the interests of animal welfare activists.

That's right, but it's about more than that. Consumers want to keep male chicks in an appropriate manner and killing male chicks after hatching is met with considerable contradiction, which even leads to a decision not to buy them.

H2: High prices for the products are not accepted by food retailers and consumers and therefore do not provide a basis for an economically viable approach.

Higher prices are accepted. Eggs from so-called brother cocks are up to 4 cents more expensive per piece and are still bought. However, it is important that the products are clearly advertised. This results in an economic basis and above all a unique selling proposition. New business areas are opening up for start-up companies in particular.

H3: The killing of male chicks is prohibited by law and the economy is forced to find ecologically sensible solutions.

Embryonic early detection is in its infancy, which is why the breeding of male chicks is still a good approach for ethical reasons. This is associated with high costs and thus remains a niche product. In the area of organic production, however, different standards apply, and consumers are prepared to pay a significantly higher price for this. In the conventional area it will still take some time, here early detection is the right approach.

H4: It is a model for the future that is becoming the standard within the EU and is also a target in other countries.

That's right, it is becoming standard, and there are already large food retailers who are using it to operate a new business field. However, the current method is not yet fully developed. But it is a question of time that it will become a legal requirement for this, in Germany and also in other EU countries. 


\section{Results and final observations}

From an economic point of view, rearing does not make sense. In the overall calculation, however, there are advantages because the losses are usually more than compensated for by higher egg prices. On average, 4 cents more per egg are charged for eggs from the so-called Brothercock Initiative and are also accepted by the losing side in order to compensate for the significantly higher costs. This not only takes account of animal welfare considerations, but also of ecological benefits.

The calculation model only serves as a basis for orientation. The actual costs are subject to market conditions and may vary considerably, particularly when products are sold. Whole animals are usable at most in the catering trade, while individual parts in the food retail trade are intended for distribution to consumers. But also, here it needs the education for the preparation and information about the rearing of the male animals that a utilization takes place in the interest of the animal protection.

The final weight of the animals is decisive in order to achieve meaningful recycling at all. Therefore, a live weight of 2 $\mathrm{kg}$ per animal should be aimed at, which is usually achieved with 120 days of rearing time, see Table 4 Cost analysis.

The main cost factor is determined by the fodder with an average of $9 \mathrm{~kg}$ per animal, which also comes from organic production. The chicks must also be of organic origin according to the guidelines of the BIO Initiative.

\section{References}

Bartussek Livestock-Welfare-Labelling, LWL-Initiative, Laying hens, Crone von der chickens for fattening, www.lwl-inititive.de

BMLE EU organic farming legislation, www.bmle.de

Crone von der, requirements BIO-Initiative, www.bio-initiave.de

EUROSTAT https://ec.europa.eu/info/departments/eurostat-european-statistics_de

EUR-Lex (Access to European Union law), http://eur-lex.europa.eu/homepage.html

REGULATION (EU) 2018/848 OF THE EUROPEAN PARLIAMENT AND OF THE COUNCIL on organic production and labelling of organic products

EU BASIS REGULATION (EC) No 834/2007 of the Council of 28 June 2007

COMMISSION REGULATION (EC) No 889/2008 of 5 September 2008 laying down detailed rules for the application of Council Regulation (EC) No 834/2007 on organic production and labelling of organic products with regard to organic production, labelling and control 